Studia Philosophiae Christianae

UKSW

$51(2015) 3$

JOSEF SEIFERT

\title{
THE SPLENDOUR OF TRUTH AND INTRINSICALLY IMMORAL ACTS II: A PHILOSOPHICAL DEFENSE OF THE REJECTION OF PROPORTIONALISM AND CONSEQUENTIALISM IN VERITATIS SPLENDOR*
}

\begin{abstract}
The basic message of Veritatis Splendor is neither a legalism nor a mere set of ethical absolutes, not even a specifically and exclusively Christian ethic. Rather, the "absoluteness" of the moral calls and the obligatory unconditional rejection of acts that are in themselves evil, lives in the heart of morality as such and especially of Christian morality. How can one understand otherwise the words, where the absolute God reveals himself as the final addressee of any inner-worldly action when he says: "you have done unto me what you have done to the least of my brothers," and: "what you not have done to the least of my brothers, that you have not done unto me"? What words might reveal more deeply the inner unity between the fundamental option and the specific interpersonal action, as well as the absolute character of the moral Act that is directed to fellow human beings? What words could insist more on the glory of human dignity, but also on the splendour of truth, and the holiness of God that radiate from these words? Perhaps this is the deepest sense of the word
\end{abstract}

* The present article is the second part of a paper that was delivered, in an abbreviated form, as keynote address, December 16, at the Confererence Ethics of Moral Absolutes Twenty years after "Veritatis splendor", Warsaw 16th-17th December 2013. As the text was too long for inclusion in the proceedings of the conference, I decided to divide it into two papers. The following is the second part of the original paper. For this reason, instead of numbering its first subtite with 8 , as it woud correspond to it as part of a whole, I continue with subtitle 1 .

Josef Seifert

seifert@institutoifes.es
International Academy of Philosophy -

Instituto de Filosofía Edith Stein

Paseo de Cartuja 49, Granada 18011, Spain 
of Saint Gregory of Nyssa: gloria Dei vivens homo est - "The glory of God is the living human person."

Keywords: intrinsically good and evil acts, consequentialist ethics, teleological ethics, moral absolutes

1. On the possible more moderate thesis of consequentialist teleologism: only external actions which are directed towards finite goods are not intrinsically good or evil. 2. Teleological ethics must admit at least one important exception to its principles: moral values. An internal contradiction and the denial of moral facts. 3. The abuse of the distinctions 'moral-premoral' and 'ontic versus moral' goods and evils. 4. Morally right/wrong versus morally good/evil acts. 5. Critique of the depersonalization of morality implied in the allegedly personalistic ethical teleologism.

\section{ON THE POSSIBLE MORE MODERATE THESIS OF CONSEQUENTIALIST TELEOLOGISM: ONLY EXTERNAL ACTIONS WHICH ARE DIRECTED TOWARDS FINITE GOODS ARE NOT INTRINSICALLY GOOD OR EVIL}

A possible version of a teleological foundation of ethical norms would be less radical than the thesis that no external human action can be intrinsically wrong: instead of denying that any act whatsoever which is directed at a finite good would be intrinsically good or evil, this thesis would only claim that external actions directed towards finite goods in such a way that they intend consequences in the (physical) world outside of the action itself, could never be intrinsically good or evil. In other words, this view would hold that from the so-called 'transcendental' inner attitudes described in the first part of my essay published separately nothing follows directly for the sphere of external actions that aim at the realization of states of affairs outside of themselves. Certainly, the adherents of this view would admit that one must always preserve a deep sense of reverence for the dignity of each human person or for the value of human sexuality. But from these intrinsically good general ('transcendental' or also 'categorial') attitudes it would not follow that actions such as abortion or torturing patients in medically sophisticated ways would be wrong always and intrinsically. Similarly, in our attitudes, we ought always to respect the dignity and the rights of other persons 
so that it is never justified to hate another person or to be indifferent as to whether she is punished justly or unjustly. Nevertheless, according to teleological ethics to commit active euthanasia or to condemn actually the innocent to death (the external action of killing an innocent man) may be permitted when the consequences of not condemning him would include, for example, racial unrest and many more deaths than would occur without condemning him unjustly. This so-called 'Caiaphas principle' would only refer to the external action, not the interior attitude that would require that, while we condemn the innocently accused man, we do so only 'with a bleeding heart'. Similarly, while hatred of a man is always wrong, it may be permitted to punish a person who has committed a hideous crime with the death-penalty. Hence not the external action of 'not killing' but only the interior attitude of loving concern is absolutely required.

The teleological thesis, thus interpreted, could be formulated in the following way: Absolute imperatives that have finite goods as their objects refer exclusively to interior attitudes and allow for any external action towards finite goods (as long as its consequences justify it). This version of teleological ethics, too, can be criticized, and in various manners.

First, this thesis denies the unity between the inner man and his external actions. In a well-known book ${ }^{1}$, Ginters presents an analysis of Ausdruckshandlung (expressive action) that seems to recognize this fact of the unity between internal attitudes and those external actions that express these inner attitudes and thus must be judged in light of a criterion other than their consequences (success). But, as Spaemann has shown in various articles critical of 'universal teleological' ethics, Ginters seeks then to reduce the value of Ausdruckshandlung to the principle of purely teleological ethics according to which the proportionality between good and bad effects of one's actions is the only criterion

1 R. Ginters, Die Ausdruckshandlung. Eine Untersuchung ihrer sittlichen Bedeutsamkeit, Düsseldorf 1976. Ginters maintains that the Wirkungshandlung (effect-directed action) participates in the moral quality and "obligatory character of the inner position (response).” See also R. Spaemann, Über die Unmöglichkeit einer rein teleologischen Begründung der Ethik, Philosophisches Jahrbuch 88(1981), 87-88. 
for determining good actions and discerning them from evil ones. At any rate, also the thesis that, while inner acts are intrinsically good or evil, external actions are right and wrong solely in view of their consequences, completely breaks up the deep unity of the person, notably the unity between her inner life (being) and her external Tat (action). It overlooks the central thesis of Karol Wojtyła's book The Acting Person, that the person's being manifests itself primarily in her free action so that between the being of the person and her actions we find an inseparable and necessary bond. The organic unity that unites the absolutely required inner attitudes with the sphere of external interpersonal actions is denied if one thinks that the intrinsic goodness of interior acts could exist without any intrinsic goodness or evilness of external actions. It is impossible to have respect for a person superactually and always, and then, nonetheless, be justified in uttering calumnies and lies about her, or beating her up, or commit partial birth abortion, ${ }^{2}$ to use just a few striking examples. Likewise, it is impossible that a doctor respects the dignity and the mystery of human sexuality, but then rapes his woman patient. This act is by its nature evil even when its effect may be that, for example by a tyrannical order and whim of a ruler, hundreds of lives are saved or hundred other women saved from rape. Here, the interior attitudes and the external actions are absolutely incompatible with each other. Hence, the version of ethical consequentialism and 'teleologism' under consideration leads at this point to a total divorce between the inner man and his outer action - a divorce which contradicts the essence of the person and which 'depersonalizes' as it were external human actions.

Consequentialist ethics denies the unity of man also in another respect. It creates an intolerable dualism between body and soul, separating the interior life of man from his bodily and embodied actions. The ambiguous term 'dualism'3 means here not the distinction between soul and body which to hold is perfectly justified by the data, but a divorce

2 The horrible form of abortion/infanticide (legally permitted in the US through President Clinton's Veto against the large Congressional vote against permitting it), in which the crane of the partially born baby, brought before into a breach-position, is crushed before the head emerges from the womb in the birth process.

3 See J. Seifert, Das Leib-Seele Problem, Darmstadt 1989, $126 \mathrm{ff}$. 
between the mental attitudes and the bodily sphere of human existence. Man's lived body is precisely - in the phenomenon of expression, in our feeling of the body from 'within', and in many other ways - organically united with the human spirit. Hence, an attitude of kindness and truthfulness towards the other is absolutely incompatible with telling him actual lies, torturing him, humiliating him, etc. (We speak here of an intelligible 'logic of expression' between inner attitudes and outward bodily behavior and do not preclude, of course, that some objective necessity such as a life-saving operation may justify the inflicting of pain on another man by a merciful doctor. Again, the principle of double-effect justifies actions of self-defense by which the aggressor is hurt or killed. Also such actions do not contradict the essence of an interior attitude of love or kindness. These cases, however, are essentially different from those in which the entire meaning, intention, and nature of the external bodily action radically contradicts the required inner attitudes. This precisely applies to the examples we used, where it is morally and even psychologically impossible that a person with purity of heart rapes a woman or performs pornographic external acts or produces indecent materials, or that a merciful and loving man tortures the innocent in order to obtain important information.) Any view, therefore, which declares the ethical quality of bodily actions to be relative to their consequences only, instead of recognizing their essential relationship to inner attitudes, contradicts the unity of body and soul both in the subject-person and in the object-person. For there are mean forms of speaking and bodily relating to another person, forms of external actions that violate essentially and necessarily the dignity both of the subject-person and of the object-person of moral actions. To this group of actions belong such deeds as unfaithfulness, sexual perversions, torture, and so on.

Finally, purely teleological ethics also contradicts the unity of the moral principle which underlies, on the one hand, morally good but fruitless and, on the other hand, successful moral actions. For, as Kant put it, it is clear that also an action that fails to be successful but was undertaken with full commitment and the activation of all our strength retains its full moral value and "sparkles like a jewel." It is clear that the success of an action as such cannot add anything to its moral value. 
But if the effects (consequences) were the sole standard for judging moral qualities of actions, this fact would become totally inexplicable. The moral goodness of the ineffective good action would have to be explained by some purely internal 'rightness' of the agent's response to a morally relevant object and to other factors (the circumstances, and so forth), while only the successful action would be explicable in terms of its consequences. But how can one and the same type of heroic action, whose success is quite uncertain at the beginning, be made dependent on two entirely different ethical principles and foundations? Given the essential sameness of the moral quality of successful and unsuccessful actions, such a dualism in the ethical foundation of external actions is untenable.

\section{TELEOLOGICAL ETHICS MUST ADMIT AT LEAST ONE IMPORTANT EXCEPTION TO ITS PRINCIPLES: MORAL VALUES. AN INTERNAL CONTRADICTION AND THE DENIAL OF MORAL FACTS}

Consider a second critique of the divorce between the ethics of external actions (praxeology) that would have to be judged by their consequences only, and the ethics of inner attitudes and virtues. This critique is both an immanent critique that will uncover an internal contradiction in most teleological positions and a transcendent critique that demonstrates that any position that would deny this important 'exception' of countless external actions from the 'teleological-consequentialist' principle would flatly contradict the moral facts.

Purely teleological ethicists themselves usually assert that moral evils themselves (as opposed to morally relevant non-moral evils) must never be included in the calculus of the good and bad consequences to be weighed against each other when deciding on which course of action to take. The reason for such an absolute interdict of, for example, actively cooperating with sin, is seen by some of these authors, for example by Bernhard Schüller, in a non-teleological factor (namely the unconditional character of moral values and disvalues). In his article, Direct Killing/Indirect Killing, for example, Bernhard Schüller writes: "It would seem that one could not do anything if the negative consequence consisted in a sin, even if 
the sin is another's. Sin is an absolute nonvalue. (...) Therefore, it must be avoided unconditionally. It is unthinkable that one could justify condoning what is morally evil. (...) It should be clear, then, that leading another into sin, as this is understood by moral theology, must be considered morally evil by its very nature. For it takes this term to mean an act which has the sin of another as its foreseen and intended consequence. (...) It may be conjectured that a permissive will and an indirect act are required as ethically meaningful categories only for moral evil." ${ }^{4}$

On the other hand, the thinkers who defend the purely teleological theory hold that (a) no non-absolute (finite, created) good can impose absolute obligations, and (b) that there are no "ways of acting which must be judged ethically right or wrong, independent of their consequences," that "a legalistic misconception of ethical norms underlies deontological norms", ${ }^{5}$ and that (c) no interhuman action is absolutely (in itself) right or wrong.

There exists a non-formal logical contradiction between these two claims ([a] to [c] on the one hand, and the claim that sin must absolutely not be actively cooperated with, on the other), at least one of which is clearly untenable because countless interhuman actions have precisely morally good or evil qualities in the other person (and in ourselves) as object. What is meant here specifically are countless actions in the field of education (moral education), sermons, moral exhortations and psychological-moral counseling, journalism, advertisement, movies and art, the engaging in, or opposing of, the business of prostitution and pornography, and so forth. It is clear that these actions are interhuman (directed towards other human beings) but - even in the opinion of defenders of ethical teleologism - absolutely good or evil because they intend directly moral qualities in other persons. Also in the opinion of teleological ethicists who grant (and mistakenly regard it even as a tautology) that moral evils must never be willed actively, such actions,

4 B. Schüller, Direct Killing/Indirect Killing, in: Readings in Moral Theology, No. 1. Moral Norms and Catholic Tradition, eds. Ch. E. Curran, R.A. McCormick, New York 1979, 141-142.

5 B. Schüller, Various Types of Grounding of Ethical Norms, in: Readings in Moral Theology, No. 1. Moral Norms and Catholic Tradition, op. cit., 184-198; 184-186. 
which clearly are interhuman, would have to be regarded as intrinsically morally good or morally evil. In addition, the unconditional character of moral values and disvalues does not derive from their being the absolute good (because they are finite goods and by no means divine) nor from the impossibility that they could give rise to a competition with other higher goods (because my morally wrong act might save the life of another person who realizes much higher moral values).

This argument against purely teleological ethics forces the adherent of that view to make a choice between two alternatives both of which are fatal for his position. Either he has to accept the fact that interhuman actions aiming at the moral qualities of another person involve a complete refutation of the theory that non-absolute finite goods cannot impose absolute obligations on us and he has to accept that inter-human actions can be intrinsically right or wrong. Or the "purely teleological ethics', in order to escape this flagrant contradiction with its foundational principle, must openly make the cynical transition from an allegedly moral and noble consequentialism, which rejects all sinful acts absolutely, to a pure Machiavellianism. Since Bernhard Schüller rejects the latter consequence, he should adopt the first one which, for the sake of avoiding what he calls 'rule-worship', he attempts to circumvent by falling into what can be called a 'morality-worship', namely a declaring finite moral values absolute and beyond any possible competition, as if they were divine, and as if it were not also true that very frequently we find ourselves faced with a choice between actions which will precisely influence positively or negatively our own or someone else's moral life. While Bernhard Schüller - followed therein also by some articles of Josef Fuchs - rejects the second (Machiavellian) solution to the mentioned alternative and tries at the same time unsuccessfully to avoid any fundamental revision of the consequentialist principle, Charles Curran and Josef Fuchs seem to go at times all the way to adopt a pure and more radical Machiavellianism which holds that the good end justifies all evil (also morally evil) means. ${ }^{6}$ This view would ultimately

6 See B. Schüller, Direct Killing/Indirect Killing, op. cit., 141 ff. For a certain lack of clarity and of committing himself to the teleological position more explicitly stated by Franz Böckle and others, see also B. Schüller, Various Types of Grounding 
also imply a moral justification for the actions of the devil and for the seduction to $\sin$, if these were undertaken in view of their magnificent consequence: redemption.

Should the proponents of the new purely teleological ethics protest and say that of course they would never embrace such an immoralist Machiavellianism and diabolical attitude, then they would have to abandon their own fundamental theory about the foundation of the ethics of external actions. Then they have to admit that there exist many external actions which are morally right or wrong intrinsically and absolutely,

of Ethical Norms, op. cit. See note 8 on C. Curran's and Franz Böckle's position. J. Fuchs seems to take - in contradistinction to some passages in Essere del Signore and against W. Korff's and A. Auer's views that a lesser moral (!) evil can be justified in order to avoid a greater one - a position similar to that of Bernhard Schüller. See J. Fuchs, "Intrinsece Malum": Überlegungen zu einem umstrittenen Begriff, in: Sittliche Normen. Zum Problem ihrer allgemeinen und unwandelbaren Geltung, ed. W. Kerber, Düsseldorf 1982, 74-91, especially 75, 90 (Nr. 2), 91. See also J. Fuchs, Good Acts and Good Persons, The Tablet (1993) Nov 6, 1444-1445. Fr. Richard McCormick asserted that Veritatis Splendor misunderstands the position of proportionalism, wrongly ascribing to it such a consequence: "The encyclical repeatedly states of proportionalism that it attempts to justify morally wrong actions by a good intention. This, I regret to say, is a misrepresentation." Richard McCormick published essentially the same article in three different places: Document begs many legitimate moral questions, National Catholic Reporter (1993) Oct. 15, 17; "Veritatis Splendor" and Moral Theology, America (1993) Oct 30, 8-11, and "Veritatis Splendor" in Focus: Killing the Patient, The Tablet (1993) Oct 30, 1410-1411. This passage can be found in America (1993), p. 10. Again, he writes: "Not a single theologian would hold that a good intention could sanctify what has already been described as a morally wrong act. And that is what the encyclical says proportionalists do. Revisionist writers should both reject and resent that." R. McCormick, Some Early Reactions to "Veritatis Splendor", Theological Studies 55(1994), 481-506. Janet Smith shows that this is not what Veritatis Splendor attributes to these authors, but that it renders their position quite precisely. See J. Smith, "Veritatis Splendor", Proportionalism, and Contraception, http://mycatholicfaith.org/index.php?option $=$ com_content\&view $=$ article \&id $=1734 \%$ 3 Averitatis-splendor-proportionalism-and-contraception\&catid $=67 \% 3$ Ajanet-smith-articles\&Itemid=133 [2015, September 15]. Among the critics of this view one should also mention - besides those already mentioned - Ramon Garcia de Haro and Fernando Inciarte. See the latter's exchange with Bernhard Schüller, in Theologische Revue (Münster) 78(1982)2. The title of Inciarte's paper is Theonomie, Autonomie und das Problem der Politischen Macht, Theologische Revue (Münster) 78(1982)2, 89-102. 
and which cannot be justified even if their effect outweighs in goodness their evilness.

\section{THE ABUSE OF THE DISTINCTIONS 'MORAL-PREMORAL' AND 'ONTIC VERSUS MORAL' GOODS AND EVILS}

A third critique of the thesis that external actions must never be judged morally except in terms of their consequences is the following. This ethic makes a highly misleading use of various distinctions (for the most part fully justified and valuable in themselves) between premoral and moral goods in order to deny that any created good could impose absolute obligations upon us. The notions 'premoral goods' and 'moral goods' and the distinction between them can have good legitimate meanings but can likewise merge into one ambiguous notion many different concepts and then be used for sophistical purposes. The distinction between the correct use and the abuse of the terms moral/premoral good shall prove helpful in the clarification of the issues at hand.

(1) Incorrect use of the correct distinction moral-premoral, when moral goods and evils themselves are called 'premoral': A first sense of premoral goods refers to what Hildebrand" called 'morally relevant goods' in the sense of those goods which are not themselves moral goods but which impose moral obligations. In regard to such morally relevant goods it is quite true that Konkurrenzialität (competitive, mutually exclusive character) is possible and that it may be demanded that one of

7 See D. von Hildebrand, Ethics, $2^{\text {nd }}$ ed., Franciscan Herald Press, Chicago 1978, 267ff. The same author, Moralia. Nachgelassenes Werk. Gesammelte Werke Band 5 , Regensburg 1980, 445 ff., where three meanings of 'morally relevant' (sittlich bedeutsam) are distinguished: a merely functional meaning of this term which refers to all those goods and values which can ground moral imperatives and are objects of moral acts (whether they are themselves moral values and goods or not); a second meaning of this term distinguishes the morally relevant but not moral goods and values from the moral sphere itself (for example, the human life as morally relevant albeit not moral good); a third sense of 'morally relevant goods' intends those goods which do not issue moral imperatives (for example, certain aesthetic values and goods) in contradistinction to those which ground moral obligations and which are then called morally relevant precisely for this reason. 
these morally relevant goods be sacrificed or be left to perish in order to save another more important morally relevant good which needs to be saved. For example, it might be necessary to allow the death of some men because any action on our part to save them would make it impossible for us to save other human persons and would thus perhaps mean the death of persons more directly entrusted to our care.

Yet, moral values and disvalues differ radically from morally relevant goods and evils that are not themselves good or evil in the moral sense. And this difference regards especially the fact that the 'competitive' nature of morally relevant goods does not at all apply to the moral sphere itself, as if we were allowed to realize one moral evil in order to avoid others or in order to save some morally relevant goods. In the first place, moral values and disvalues have, as we have seen, a peculiar kind of (existential) absoluteness which is radically different from the absoluteness of God but which nevertheless forbids realizing moral disvalues for the sake of any other higher goods (even when this is actually possible, as in the case in which a sin saves the life of a morally much better man than we are or in the case in which sin would be committed in view of redemption). In the second place, we need to remember that those morally relevant goods that are not themselves moral goods (also moral goods and evils are morally relevant goods and some of our preceding reflections referred to them) do not possess the same 'absoluteness' by which morality itself is characterized. Hence the 'competitive mutual exclusiveness' that in the case of some morally relevant goods justifies their destruction does not justify the violation of morality itself. For this reason, too, it is absolutely wrong to regard moral goods and evils - as long as one prescinds from their consequences - as merely 'premorally good or evil', because such a position precisely implies the confusion between the specifically moral (and specifically, the morally obligatory) sphere and the domain of extramoral morally relevant goods within which the calculation of the higher of mutually exclusive goods can have some rightful place.

Moreover, as Carlo Caffarra rightly points out, morally 'relevant' goods participate in the absoluteness of the moral sphere itself when they become morally relevant, i.e., when they concretely address a moral imperative to us. This moral relevance of a good arises only in its 
encounter with a person who is specifically related to it. For example, the cry for help of a needy person is not in itself morally relevant; it becomes so for someone who passes by and hears it. Morally relevant goods such as the need of a human being cease to assume this absolute character when they appear outside of the context of a moral action, or rather when their moral relevance is potential and does not address somebody. When Socrates is commanded to take the life of an innocent man by murder, the value of this life unfolds its moral relevance and Socrates is absolutely forbidden to take it even in order to save his own and other lives; because to kill in this case is immoral and the dignity of the one innocent man partakes in the absoluteness and superiority of moral values over all extramoral values. Hence it is here not a question of many lives against one but what is at issue is the incomparable and 'absolute' primacy of the obligation to avoid moral evil versus the coming into existence of extramoral evils. Of course, one needs to understand, in addition, that moral good and evil (moral relevance) is not restricted to the totality of good and evil effects of human actions to be weighed against each other (as Josef Fuchs argued against Caffarra), but that certain modes of behaving towards created goods are intrinsically morally good or evil because their object-goods are morally relevant directly and in reference to specific actions.

The weighing of good versus bad effects of human actions as basis of moral decisions would, however, be a proper consideration when the moral theme does not exclude certain actions and when we have merely to select the higher value, as when we can save one life in one part of town by quick medical action and two hundred in another part of the same town. When we consider this fact it becomes clear that Grisez, Boyle, and May offer a questionable argument against ethical consequentialism. ${ }^{8}$ They maintain that there is an absolute incommensurability of the elementary goods in such a way that it is impossible to compare them in terms of hierarchical superiority. In reality, however,

8 See, for instance, G. Grisez, J. M. Boyle, Jr., Life and Death with Liberty and Justice: A Contribution to the Euthanasia Debate, Notre Dame, Ind., and London 1979; G. Grisez, Abortion: The Myths, the Realities, and the Arguments, New York and Cleveland 1970. 
'quantitative' as well as 'qualitative' hierarchical gradation within the so-called elementary goods must be recognized and is also presupposed for any meaningful application of the principle of 'double effect'. If it is a mere question of the goods on the object-side, of course a quantitative hierarchy of goods applies in that it is better to save two hundred human lives than just one (which does not exclude that special obligations towards the one person may bind me to save her life rather than the two hundred). Similarly, when it is a question of permitting that either our life, or our honor, or our moral integrity, or our physical integrity be violated, qualitative hierarchical points of view play the decisive role, even if it is true that many different points of view (rank of value, indispensability, and the like) come into play here so that one clear 'ranking' of these goods (life, freedom, honor, moral integrity, health, etc.), as if these goods were 'higher' or 'lower' simply speaking and under all relevant points of view, is impossible. Nevertheless, it is clear that life ranks higher than health, or that moral integrity is a higher good in itself than life, and so forth.

This hierarchical gradation of the 'elementary goods' is not only to be admitted in the context of any meaningful application of the principle of double-effect but also for the insistence on the absolute priority of the moral point of view over extramoral considerations without which primacy the consequentialist position cannot be refuted at all. The decisive point that the moral drama and moral obligations are more absolute than the 'premoral' sphere of morally relevant goods and that these goods, when their dormant moral relevance becomes actual, partake in the absoluteness of morality itself, as Caffarra puts it well, could also not be seen without recognizing a hierarchy of goods and a 'negative hierarchy of evils'.

In order for consequentialism to be refuted it is of crucial importance to understand precisely this point, which is contained in the famous Socratic thesis in Plato's Gorgias that "it is a greater evil for man to commit injustice than to suffer it." This truth cannot be grasped without understanding the fact that the moral evil of an action is precisely different from the

9 See C. Caffarra, Die Unmoral der Empfängnisverhütung, Theologisches (1981) 133, 4078-4088. 
non-moral but morally relevant good of health or life on the object-side and outweighs the latter by far. There is, for example, a great difference between allowing/not preventing that a false sentence be written by another (where the evil of a false statement is given as such), and myself writing or asserting it (where it is morally relevant and issues an obligation to me which to violate brings about a grave moral evil). Thomas More, to take a concrete example, died for the difference between these two cases. He would not have been obliged to die in order for the false statement not to be made by Henry VIII, but he was obliged not to agree to make, under oath, the false statement (about the ecclesiastic supremacy of Henry VIII) himself. Morally relevant goods and evils (from which moral calls issue but which are not themselves goods and evils in the moral sense, such as life) and moral goods and evils are radically different from each other. The physician is not obliged to sacrifice his life for the life of a dying patient (except when he has a strict medical duty to take care of a patient afflicted by the plague or another deadly disease), but he is obliged rather to die than to commit the immoral acts of euthanasia or abortion, or others. Moral evils have a peculiar form of 'absoluteness' through which they reject the absolute good and offend God, whereas extramoral evils (which can become relevant for morality) do not. The reason for moral relevance does not lie exclusively in the image-of-God-character of the human person or in the fact that a good or evil is related to the person (because not all personal values are morally relevant and also animals possess a certain moral relevance).

Thus, we conclude that a serious ethical confusion is being introduced as soon as moral goods and evils themselves are called 'premoral' as long as they are regarded independently of their consequences. This is an illegitimate usage of the term 'premoral' goods because it is entirely based on the consequentialist-utilitarian error. This sense of the discussed pair of distinctions must not be confused with the sense in which morally relevant (not moral) goods are called 'premoral' because some (potentially) morally relevant goods really are not actually morally relevant objects of human action when they are not seen in reference to consequences. This applies, for example, very clearly to the case in which the moral relevance of a certain true statement depends on the effects it will have on society, on the reactions the person to whom it 
is made will have, etc. In another sense, it applies also to the moral relevance of a human life in danger, whose actual moral relevance and originating of moral obligations may be suspended if the action of saving it prevents me from saving hundred other lives on the other side of a sinking ship.

(2) An incorrect use of the distinction when it is denied that premoral goods can impose absolute moral obligations: A second confusion results as soon as those morally relevant goods and evils which are not moral goods and evils are interpreted in such a way that no moral response due to them could ever be absolutely required. Then it is forgotten that also these morally relevant goods, insofar as they demand a certain moral response, partake in the absoluteness of the moral sphere. Hence also non-moral morally relevant finite goods can issue absolute moral imperatives. (I am thinking here especially albeit not exclusively of the sixth sense of 'absolute' distinguished above.)

(3) Incorrect use of the distinction between moral and premoral goods when all moral obligations are called 'prima facie' obligations: The actions corresponding to prima facie obligations could likewise be called 'premoral goods'. Such prima facie obligations as pacta sunt servanda do not as such and necessarily make each and every action immoral which fails to keep a pact. Only when a prima facie obligation is not suppressed by a higher one, is a moral obligation actually present. Therefore, one could say that fulfilling the terms of a contract is not intrinsically and necessarily morally good; for example, it is morally evil when a surgeon keeps a pact to perform an immoral operation. Hence, actions which obey the principle pacta sunt servanda are good only in a 'premoral sense', which means here that they are normally morally good but can under circumstances (as when the contract itself is intrinsically immoral) become morally bad.

As long as it is clear that one speaks here of 'premoral' in an entirely different sense, it is legitimate to say that obedience to prima facie duties is good only premorally and that the real moral value of fulfilling a prima facie obligation depends on the presence of additional factors which make the observation of these principles in the actual situation specifically morally good. 
But an abuse of the term 'premoral' results from a generalization of this case of prima facie obligations, i.e., from regarding all obligations as prima facie obligations only, denying the difference between non-absolute prima facie duties, i.e., obligations which can be suppressed by higher conflicting ones, and absolute (i.e., non-suppressible) duties. From a universal application of the last distinction between 'premoral' versus 'moral' it would follow that no action is intrinsically morally right or wrong.

The denial of intrinsically good or evil (right or wrong) acts rests largely on this entirely different sense of the moral-premoral distinction, which by definition eliminates any acts or actions that could be morally forbidden universally, i.e., under all circumstances. We have already found, however, that non-absolute, finite goods impose ethically speaking absolute obligations, both in reference to inner responses and stances and in regard to some external actions. Thus, the universal claim that no type of action as such is intrinsically morally right or wrong is false.

\section{MORALLY RIGHT/WRONG VERSUS MORALLY GOOD/EVIL ACTS}

Finally, another totally different sense of premoral versus moral goods and evils simply designates the distinction between morally wrong (false) and right actions, on the one hand, and morally good and evil ones, on the other. As was recognized by most ethicists of the past, the objective nature of an action (the materia) is not sufficient to account for moral goodness or evilness. Rather, knowledge (consciousness) and actual possession of freedom are presupposed for the coming into existence of moral properties including the morally right or morally wrong character of actions that does not exist for animals deprived of reason and freedom nor for small infants incapable of using their intellect and free will. Nevertheless, a decisive distinction exists between the objectively morally wrong or right nature of human acts and the actual morally good or evil character of human acts. For if a person innocently does not understand that an act of euthanasia is morally wrong, it would remain wrong but not be morally sinful to commit it. In the discussion surrounding purely teleological ethics this distinction 
is frequently confused with the preceding ones, and the obvious fact of the validity of this distinction (which was always made in the tradition in that it was recognized that moral responsibility and knowledge are required to make an objectively morally wrong act immoral or sinful) must not be invoked to justify the above-mentioned illegitimate usages of the 'moral-premoral' distinction.

(1) Ontic versus moral goods and evils: In teleological consequentialism we also find another fundamental abuse: that of the important distinction between moral and ontic goods and evils. All extramoral ontic goods are distinct from moral ones and must be perceived in their clear difference from them, although there are many ontic goods, such as human life, which make moral claims upon us. Human actions are directed towards such goods as the life that we attempt to save. Moral values, as Scheler puts it, appear "on the back of the moral action" because the action focuses primarily on the realization of the ontic goods that are its object. The extra-moral ontic goods in relation to which the moral act unfolds as value response or in other modes do not make the absolute claim upon us which moral goods themselves would make. It is true, for example, that circumstances and other calls may force us to abandon the life of a human being that, under these circumstances, we are no longer obliged to save. It is true that these goods are not imposing the same 'absolute duty' upon us which morality itself contains.

But the question is precisely: what is the relationship of these ontic goods, which Kant classifies as objects of inclination and as natural goods, to moral goods?

We have to exclude three fundamental misunderstandings that lead to ethical errors and attempt to recognize, positively, important ethical truths concerning the relation between the moral act and ontic goods that are its object:

(2) The first misunderstanding we need to exclude is that these ontic goods - because of their finitude and because of the absoluteness of the moral act - have nothing whatsoever to do with the origin of moral oughtness. This is the fundamental mistake of Kantian ethics which, recognizing the discrepancy between ontic goods and moral goods, believes that the source of the absoluteness of the moral ought must lie not in the object of the act but in the subject, in the pure form of the 
categorical imperative. Kant believes that the object of the moral act can never justify the moral ought, which must be explained a priori by the subject. While we do not wish to deny that the subject, and the personal subject's encounter with objects, is crucial for the arising of moral oughtness, which never lies in the object or ontic good alone, the moral imperative still originates intelligibly in the nature and value of objects and in the imperative issuing from them. Thus, for example, the ontic good of the dignity and freedom of persons addresses its call for proper recognition to the free agent. The raison d'être of the moral act is, in a certain sense, to give the due response to certain ontic (morally relevant) goods that deserve recognition and affirmation by the agent from a moral point of view. This is expressed in what Karol Wojtyła, Tadeusz Styczeń, and Andrzej Szostek regard as the foundational moral norm: persona est affirmanda propter seipsam. Not only in the encyclical, also in his philosophical work, Karol Wojtyła has elaborated this personalistic foundation of ethics in an amazingly profound way. ${ }^{10}$

${ }^{10}$ See K. Wojtyła, Love and Responsibility, trans. by H.T. Willetts, Ignatius Press, San Francisco 1993, in Pope John Paul II, Uomo e donna lo creò, Città Nuova Editrice/ Libreria Editrice Vaticana,Vatican City 1987. See likewise K. Wojtyła, A. Szostek, T. Styczeń, Der Streit um den Menschen. Personaler Anspruch des Sittlichen, Kevelaer 1979, 31 ff., 94 ff., 144 ff. 10.

While often a eudemonist language (that is not foreign to Aristotle and even to Thomism) reigned in Catholic moral theological literature, according to which the last and highest goal of the person would be his own happiness, the self-transcending structure of the moral act as value response, i.e. a response due to a good in itself and for its own sake, is quite clearly expressed in Veritatis Splendor, 19. In Veritatis Splendor we find a clear rejection of the error as if the morally good action was motivated primarily or even exclusively by one's own self-realization. As much as happiness is a secondary motive and a result of the moral act, we must emphasize that the primary motive of the moral act and of love should be the intrinsic value of the human or of the divine person whom we ought to love for his own sake because our loving affirmation is due to the person. See J. Seifert, Was ist und was motiviert eine sittliche Handlung?, Salzburg 1976, Qué es y qué motiva una acción moral?, presentación de Alfonso López Qintás, tradd. de y ensayo introductorio de Mariano Crespo, Centro Universitario Francisco de Vitoria, Madrid 1995. Also in the benevolence of love and in the affirmation of the objective good for the other person from the point of view that it is good for him or her we encounter this transcendence of a moral act, this 'for the other's sake'. Without this element the moral act or love remains egocentric and would not deserve the name of 
Thus, there is an important relationship between moral and ontic goods, a relationship which Kantian ethics does not recognize, partly because Kant has a conception of the relation between a priori necessities and experience which forbids him to recognize that ontic goods could be understood in their essence in themselves and that absolutely

love. Long before Kant's penetrating critique of eudemonism in his Grundlegung zur Metaphysik der Sitten, in: Kants Werke, Akademie-Textausgabe, Berlin 1968, Bd. IV, Duns Scotus has pointed this out. See J. Seifert, A volontade como perfeição pura e a nova concepção nãoeudemonística do amor segundo Duns Scotus, traduzido do inglés por Roberto Hofmeister Pich, Veritas, Philosophische Fakultät, PUCRS, Porto Alegre, Brasilien 2005, 51-84. Also Max Scheler, Frankl and other thinkers, particularly Dietrich von Hildebrand, have shown the deformation and counterproductive distortion of the quest for happiness, if our happiness is considered the single or supreme and final goal of the moral act, and the transcendence of the moral act is forgotten. See D. von Hildebrand, The Nature of Love, trans. John F. Crosby with John Henry Crosby, South Bend 2009, ch. 4-9, especially ch. 7. See also J. Seifert, Dietrich von Hildebrand on Benevolence in Love and Friendship: A Masterful Contribution to Perennial Philosophy, Journal of Philosophical Inquiry and Discussion: Selected Papers on the Philosophy of Dietrich von Hildebrand, Quaestiones Disputatae 3, 2(2013), 85-106. In Christian morality, this transcendence, this losing one's soul for Christ's sake, gives this transcendence of love an entirely new weight and personalistic ethics has reached a far higher expression in it; it would be appropriate to say that if the role of God as the source of our happiness were the only thing we knew or loved in God or in the love of Christ and the worship of God, our "religion" would be anti-religious.

Just this specific personalistic moment is considered by Pope John Paul II to be one of the most important dimensions of the new Christian morality. In this context, a number of passages of VS would make an in-depth investigation desirable: Consider for example the beautiful and unconventional interpretation John Paul II gives, in the first chapter of Veritatis Splendor, to the conversation of Jesus with the rich young man. To see the novum of Christian morality, we might also consider another moment, recently emphasized by Pope Francis in Evangelii gaudium: the radical reversal of the direction of love between God and us, highlighted by Max Scheler. The love between God and man in Christianity begins, something unthinkable in ancient thought, in the love of God for us. Moreover, we might speak of a Holy madness of divine love not known in any other religion: that God loves us until choosing for our sake the most excruciating passion and death on the cross such that our love is only a weak response to this immense love; and analyzing the newness of the Gospel, we might also point to the personal embodiment of the moral law in a person, the new role of Holiness or the paramount role of grace and humility, love and mercy, as well as the communio personarum play as foundation of Christian virtues. 
necessary moments such as the moral imperative could be grounded in the essence of the object of the moral act although it is an object of experience. Yet, if one recognizes and brings to evidence that in and through the object of experience also essentially necessary facts disclose themselves to us, Kant's reason for denying that the intelligible essence of objects of experience can be the origin of moral imperatives and that we can recognize moral imperatives related to the objects of moral acts is refuted.

(3) We have to exclude two possible misinterpretations of the nature of the relationship between moral acts and their objects.

A. First, the misunderstanding must be avoided as if the moral act had only the function of a means through which the respective ontic goods would be brought about as consequences. This interpretation of the relation between moral act and ontic good, which is its object, forgets that many moral acts (such as purely interior stances a person takes towards others, as love or envy) are bearers of moral qualities without having any function of realizing goods that are extrinsic to the act. Clearly, at least their relationship with their object must be entirely different from a means-end or a cause-consequent-relationship. All goods endowed with intrinsic value and preciousness make a call upon persons who are able to understand them that they ought to acknowledge them in freedom or by a rational affective response. All value-bearing goods demand to be affirmed by persons in accordance with their value-merit, with what is due to them. The due-relationship, which is fulfilled in the adequate value-response, demands not only to be respected for the sake of man and his fulfillment but also and primarily for the sake of giving the good, which calls for an adequate response, its due. This response may or may not increase the happiness of the object-person to whom it is directed, as in the case of the worship of God, which does not increase his Blessedness. Nor does man have to give the due response primarily for his own sake, in order to become happier. Regarding this point, Hildebrand's concept of the due value response and Wojtyì's conception of the principle of personal ethics "persona amanda propter 
seipsam" broke with the eudemonism characteristic of many schools of ethics including much of Thomistic ethics. ${ }^{11}$

Man ought to give his response primarily for the sake of the good itself, for the sake of its intrinsic preciousness and worth: because it is right and just and good - only secondarily because it also fulfills his own objective good. Hildebrand has profoundly investigated these dimensions of the person's response to goods and values and has made these investigations fruitful for ethics. This due-relation itself and its fulfillment in the adequate response are not reducible to the ontic good that is the object of our response. This due-relation and the value that lies in its fulfillment are something radically new with respect to a given ontic good itself. Especially persons, and the unique dignity which they possess, call for such an affirmation and respect which is due to them. This was recognized by Kant in one of his formulations of the 'categorical imperative' which is not 'formal' but has distinct reference to the object of the moral acts, namely persons, forbidding that these be ever treated as means only and not simultaneously as ends in themselves. Kant gives the profound reason that persons possess an inherent 'absolute' value (worth), an absoluten Wert, which is not relative to inclinations or other dispositions of the subject but resides in the objective nature of persons. All of this presupposes the relation between goods and persons. It is an

${ }^{11}$ See on this K. Wojtyla, A. Szostek, T. Styczeń, Der Streit um den Menschen. Personaler Anspruch des Sittlichen, Kevelaer 1979, and T. Styczeń, Zur Frage einer unabhängigen Ethik, ibid., 111-175. See also: A. Laun, Die naturrechtliche Begründung der Ethik in der neueren katholischen Moraltheologie, Wiener Dom-Verlag, Wien 1973. See also: D. von Hildebrand, The Nature of Love, trans. John F. Crosby with J.H. Crosby, South Bend 2009, ch.7; 5; 8-10. See likewise J. Seifert, Dietrich von Hildebrand on Benevolence in Love and Friendship: A Masterful Contribution to Perennial Philosophy, Journal of Philosophical Inquiry and Discussion: Selected Papers on the Philosophy of Dietrich von Hildebrand, Quaestiones Disputatae 3, 2(2013), 85-106. See likewise A. Laun, Das Gewissen. Oberste Norm sittlichen Handelns, Innsbruck 1984; Das Gewissen - sein Gesetz und seine Freiheit. Anmerkungen zur heutigen Diskussion, in: A. Laun, Aktuelle Probleme der Moraltheologie, Herder \& Co., Wien 1991, 31-64; Great Thomists who criticized ethical eudemonism include Jacques Maritain, Joseph de Finance, and Cornelio Fabro in his Riflessioni sulla Libertà, Magggioli, Rimini 1983, i-xi, 13-132. 
arch-datum that can only be understood intuitively but is as evident as the first principles of logic or mathematics.

As we have seen, above and beyond the presence of a good endowed with an intrinsic preciousness, 'moral relevance' is required in order for our stance to that good to be bearer of moral goodness or evilness.

Against this background, the errors of an ethic become manifest which concentrates only on counting and weighing the consequences of actions in the sphere of ontic goods (which stand on the object-side). For clearly, the due response or the violation of it may express themselves as well in purely interior virtues or vices, in attitudes and stances of persons, as in external actions. Both interior stances, which do not even have external consequences, and actions in the world, however, must be judged not solely in accordance with their consequences but with reference to their inherent adequacy or inadequacy to their object. If a man kills another one or tortures and humiliates him, his act is evil not simply because it results in death, which can likewise be the case with a legitimate and well-intentioned operation, but because this action manifests a response to the person which stands in violation of her morally relevant dignity and worth. This does not exclude any teleological directedness to consequences of acts. Of course, the right response involves where possible the attempt to realize, protect, or save the morally relevant good by means of external action. Moreover, the moral imperative and the moral relevance of the good also require that we do also what is objectively good for the object-person of our act, that we do what is useful for him. Yet - and this is the decisive point - our act is good or evil not simply for the reason of its consequences but because it realizes the right and just response to that good. And even the act that aims at external results is to be judged morally not by its actual success but by the internal being and personal structure of 'justness'.

B. The most obvious immediate ethical consequence of the described different conceptions of the relationship between moral act and ontic good relates to the recognition or negation of intrinsically permitted, intrinsically wrong or right (obligatory) actions. If only the consequences of actions count, consequentialism and teleological ethics are correct. Then the moral character of a person's action results only from her weighing the consequences of her actions. If this is so, the destruction 
of morally relevant 'ontic' goods for the sake of preserving other and higher ones is always permitted. There are, then, no longer intrinsic and essential relationships between moral actions and their objects. Under these assumptions, a revolutionary concept of the relation between moral and ontic goods follows.

If the principle of 'due response' to morally relevant goods is introduced, the morality of internal acts as of external actions flows primarily from the same source. The moral character of a human act is due, namely, to the inner justice, rightness, and goodness of the free response of a person to that ontic good which, in its moral relevance, is the direct object of the action and intention of the agent. ${ }^{12}$

We have seen, however, that with the person's encounter with ontic goods their moral relevance becomes actualized and they partake in the absoluteness of the moral sphere itself. As soon as they address their call to persons to give the due response to them, the moral drama unfolds. And then the respective ontic good is not to be considered alone, in isolation, as it were, from the ethical subject. Rather, in the intrinsic connection of ontic goods, with the moral obligation or call and with the moral response, the same seriousness and unconditional respect which moral values themselves command is communicated also to ontic goods inasmuch as they stand in the moral situation. The sanctity of human life that does not appear actualized in its morally obligatory character, when said life is destroyed as the side-effect of a morally legitimate action, appears in the drama of justice or of murder in its whole depth and demands with moral sovereignty and absoluteness the morally adequate response. In fact, the new and absolute moment of moral calls and obligations enters into the objective situation and imbues the ontic goods with moral weight and seriousness, as long as they remain in this moral context. For example, as long as the human fetus is not just dying or living by natural causes but the object of being killed or not killed in abortion, it is connected with the whole weight of the moral question - as opposed to the situation in which its death is caused by

12 See J. Seifert, Was ist und was motiviert eine sittliche Handlung?, Salzburg 1976, Qué es y qué motiva una acción moral?, presentación de Alfonso López Qintás, tradd. de y ensayo introductorio de Mariano Crespo, op. cit. 
natural causes or also by the removal of a cancerous uterus. Thus, when the potential moral relevance of life is actualized in a concrete encounter between ontic good and moral act, the principle holds: to violate the morally relevant ontic good and the obligatory moral response to it is intrinsically wrong because it includes a violation of morality itself. The moral in this sense is in the world, not transmundane. It has to do with the concrete Gestalt of actions towards inner-worldly goods. To violate them is to wrong the moral order and to offend the absolute good; to act rightly towards them is to act rightly in itself and, at least implicitly, towards the absolute Good, towards God.

It becomes manifest that it does man no good, as Socrates puts it, to flee death (an ontic evil) if the quicker (moral) evil of injustice takes possession of the soul, and that it serves man nothing even if he gains the whole world but suffers damage in his soul.

\section{CRITIQUE OF THE DEPERSONALIZATION OF MORALITY IMPLIED IN THE ALLEGEDLY PERSONALISTIC ETHICAL TELEOLOGISM}

The champions and followers of the new utilitarianism of 'purely teleological ethics' pride themselves with getting away from an ethical legalism and with rediscovering the autonomy and dignity of the person. Their position seems to recognize the concreteness of a person's situation and of her problems. Seemingly, it gives full weight to each individual's moral decisions and frees man from being enslaved by some universal standards whose generality of 'always' or 'never' allegedly forgets the concrete moral subject and the infinite complexity of situations which permits only an ut in pluribus (in the majority of cases), if morality is to avoid the reproach of being a depersonalizing legalism and 'rule-worship'.

However, we discovered upon closer examination that precisely the thesis that the consequences of actions alone provide the clue for their moral character implies a total depersonalization of morality, already for the reason that the very same good consequences that allegedly justify a concrete action could in many cases also be brought about by impersonal causes. Consequentialism (we prescind here from the doctrine of 'fundamental options' as principle of goodness which, as we tried to 
show above, contradicts the consequentialist foundation of ethics) forgets one of the most obvious facts of ethical experience, namely, that the subject's stance, knowledge, and intention are decisive for the constitution of moral qualities. A rigorous consequentialist position results in a total overlooking of the factor of motivation and Gesinnung which distinguish an action of a Pharisee from that of a saint, also when both actions have exactly identical consequences. Kierkegaard in his critique of Hegel's world-historical ethics, Kant in his critique of utilitarianism, and Plato in Republic II (in his interpretation of the story of the ring of Gyges and in his comparison of the best life with the worst consequences and of the worst one with the best consequences) bring out forcefully the untenability of ethical consequentialism which makes the moral value of an act dependent on effects which are external to its essence and its personal relationship to its object and end.

When we consider the interior motivation of external actions, it also becomes evident how utterly untenable is any separation between inner acts and outer actions because the deepest source of value of an external moral action lies precisely in the inner free stance of the agent which is based on the knowledge of morally relevant goods. Phariseism or ressentiment can totally vitiate any external action regardless of its excellent consequences. Thus, its moral goodness or rightness cannot be grounded in its relation to its effects.

Another aspect of the depersonalization of morality through consequentialist teleologism consists in this position's overlooking many important moments in the objective but personalistic structure of the human action itself. Thomas Aquinas has clearly made the decisive distinction between finis operis (objective essential 'end' of an action itself) and finis operantis (subjective motive and intention). Both of these moments concern the conscious and free structure of the human action and involve the immense difference between merely foreseen and indirect 'consequences' and purposes of an action, on the one hand, and intended and direct consequences, on the other. Hence both of these decisive elements of moral actions are lost sight of as soon as the essential role of the person's intention, inner stance, and motivation is overlooked as formative for the moral value of the (external) human action and as totally irreducible to that action's causal function of producing 
consequences. The same applies to the crucial distinction between object (in the broader sense of, for example, the persona affirmanda propter seipsam which plays such a crucial role in the personalistic ethics of Karol Cardinal Wojtyła and of Tadeusz Styczeń ${ }^{13}$ ) and the Sachverhalt which is the direct object of the external action as such, the fact to be realized by the agent. Only the latter (the state of affairs directly realized by the agent) can at all be recognized by teleological-consequentialist ethics because the object of an action in the broader sense (for example, the person herself in regard to whom I act) is not a consequence of my action, has no further consequences initiated by my action itself, yet should be affirmed in and through any external action in order for this action to have any moral value. Any action that aims at a human or divine person, for example, is morally good or evil primarily because it expresses a loving affirmation or hateful negation of the person. This loving affirmation of the person as such is in no way identical with that side of the action that realizes states of affairs outside the human act itself. Yet, only the states of affairs directly realized by human actions have consequences. Thus, consequentialist and teleological ethics take into account only an extremely limited part of the entire object of the external moral action. Consequentialism thus distorts the nature of moral action by cutting out the primary object(-person) at which the action is directed. This is a particularly great flaw in a theory of medical ethics

13 The various critical contributions of Tadeusz Styczen on the subject of a purely teleological ethics are not yet published in any language besides Polish. The fundamental ethical position of T. Styczeń, however, in which the "person is to be affirmed because of herself (because of his or her dignity)" plays a central role, and also the ethical position of Styczeń's philosophical teacher (Karol Wojtyła - Pope John Paul II), is outlined excellently in T. Styczeń's article, Zur Frage einer unabhängigen Ethik. Many other authors, for example Grisez in some articles, have emphasized the personalistic nature of morality and have rightly pointed out how especially "Christian morality is a morality of the heart" and that the loving attitude of the heart is far more important than the consequences of our actions. For from here proceed all the motivations and intentions which account for the specifically moral and personal character of human actions, also external actions.

In reference to the personalistic anthropological foundation of ethics in the Polish school see also the book by R. Buttiglione, Il pensiero di Karol Wojtyła, Milano 1982, especially $121 \mathrm{ff}$. 
for here the moral relevance of the person of the patient to be affirmed by a physician and nurse infinitely exceeds the small fraction of her reality, which medical art can improve or change; moreover, even that part of the object (Sachverhalt) which consequentialist ethics admits is reduced to the same level as those mere effects of an action that are not the intended finis of the act. To overlook such central distinctions or to be unable to account for them implies another aspect of the depersonalization of morality that objectively is implied by 'purely teleological ethics', however much this may be opposed to the intentions of its proponents.

The specifically personal dimension of morality, nay the person herself, is not only overlooked but also actively negated in this ethics. Instead of a new personalistic ethics, it is an anti-personalistic ethics. For if the person and her actions become a mere means with respect to consequences, he or she is degraded as person. Such a consequentialism goes directly against the personalistic principle enunciated by Kant (and in Love and Responsibility and elsewhere by Karol Wojtyła) that "a person must never be treated solely as a means but always simultaneously as an end in herself." Any reduction of the moral value of an action (as well as of object-persons of human actions) to mere functions with respect to results is thus the moral attack on the person - in the name of ethical personalism. This anti-personalism of ethical consequentialism emerges especially when one considers the essential truth about the person formulated by the Platonic Socrates in the Republic, the Gorgias, and elsewhere, that moral goodness is the good for the person, the 'proper good of the soul'. If, then, the person is reduced in what is the perfection of man and of any person qua person to the function of acts for consequences, we are confronted with a program of radical anti-personalism and, as Tadeusz Styczeń has shown, of - anonymous - anti-theism. ${ }^{14}$

Thus we find, as ultimate consequence of this position, a radical instrumentalization of morality. In spite of all subjective intentions to achieve a new personalism, and the talk of a new personalism in purely teleological ethics, we must speak both of a forgetfulness of the ethical subject (person) and of the specific moral dimension of morality, and of an active attack

${ }^{14}$ See Tadeusz Styczeń's contribution to the volume, Menschenwürde: Metaphysik und Ethik, ed. M. Crespo, Heidelberg 1998. 
on the person. To overlook and to degrade both the person as moral agent and the specifically moral dimension of moral acts constitutes perhaps the most fundamental defect of the new consequentialist teleologism in ethics. (The emphasis on a transcendental dimension of morality in the 'fundamental option' cannot remedy this serious flaw, not only because it is inconsistent with the utilitarian-consequentialist part of this position, but also because it banishes the personal motivation and decision into a sphere completely outside that of inner-worldly human actions, which are to be explained ethically.) In the calculus of effects to which this position leads, the primary end of the world that lies in moral goodness (and in the glorification of God, which solely can be realized through moral values) is forgotten. The specifically moral qualities as such are usually not included in the Güterabwägung (calculus of goods and evils in view of their proportionality). This exclusion of moral values themselves from the relativity of finite goods contradicts the thesis that no finite (created) good can command unconditional respect. Moreover, it is usually not primarily because of a respect for the absoluteness of the moral sphere that moral values are not included in the Güterabwägung but rather because almost exclusively morally relevant goods are considered by this new ethics. The free love of the good in accordance with its true value, the heart of morality, cannot even come into sight when the inner invisible intention (the measure of love, for example), which counts ultimately in the determination of an action's moral value, is overlooked and only the consequences are stressed.

The focal point of the spiritual universe, the knowing, free, and conscious assent to the good, must, however, never be forgotten but rediscovered and discovered ever more deeply, if a new ethics and not the destruction of ethics is to be achieved. It is the concern for this most central value of any person, human or divine, moral goodness, which motivated this critique and has, in its pure positive significance, precedence over any critique. All effects and consequences of moral actions put together cannot amount to the value and sublimity of the smallest moral act or love which surpasses all non-moral goods in value and belongs to an entirely new and higher order.

Many authors who fight, in the name and under the semblance of personalism, against the alleged "legalism" of Veritatis Splendor in fact 
abandon a central content of each personalist ethics and of the whole tradition of religious moral teaching. The basic message of Veritatis Splendor is neither a legalism nor a sect of ethical absolutes, not even a specifically and exclusively Christian ethics. Rather, the "absoluteness" of the moral calls and the obligatory unconditional rejection of acts that are in themselves evil lives in the heart of morality as such and especially of Christian morality. How can one understand otherwise the words, where the absolute God himself reveals Himself as final addressee of any inner-worldly action when He says: "you have done unto me what you have done to the least of my brothers," and: "what you not have done to the least of my brothers, that you have not done unto me."? What words might reveal more deeply the inner unity between the fundamental option and the specific interpersonal action, as well as the absolute character of the moral act that is directed to fellow human beings? What words could insist more on the glory of human dignity, but also on the splendour of truth, and the holiness of God that radiate from these words. Perhaps this is the deepest sense of the word of Saint Gregory of Nyssa: gloria Dei vivens homo est - "The glory (glory) of God is the living human person."

\section{REFERENCE}

Buttiglione R., Il pensiero di Karol Wojtyła, Jaca Book, Milano 1982. Caffarra C., Die Unmoral der Empfängnisverhütung, Theologisches (1981)133, 4078-4088.

Fabro C., Riflessioni sulla Libertà, Magggioli, Rimini 1983.

Fuchs J., "Intrinsece Malum”: Überlegungen zu einem umstrittenen Begriff, in: Sittliche Normen. Zum Problem ihrer allgemeinen und unwandelbaren Geltung, ed. W. Kerber, Düsseldorf 1982, 74-91.

Fuchs J., Good Acts and Good Persons, The Tablet (1993)6, 1444-1445. Ginters R., Die Ausdruckshandlung. Eine Untersuchung ihrer sittlichen Bedeutsamkeit, Patmos Verlag, Düsseldorf 1976.

Grisez G., Abortion: The Myths, the Realities, and the Arguments, Corpus Books, New York and Cleveland 1970.

Grisez G., Boyle J.M., Jr., Life and Death with Liberty and Justice: A Contribution to the Euthanasia Debate, University of Notre Dame Press, Notre Dame, Ind., and London 1979. 
Hildebrand D. von, Ethics, 2 ${ }^{\text {nd }}$ ed., Franciscan Herald Press, Chicago 1978. Hildebrand D. von, Moralia. Nachgelassenes Werk. Gesammelte Werke Band 5, Josef Habbel, Regensburg 1980.

Hildebrand D. von, The Nature of Love, trans. John F. Crosby with John Henry Crosby, St. Augustine's Press, South Bend 2009.

Inciarte F., Thenomie, Autonomie und das Problem der Politischen Macht, Theologische Revue (Münster) 78(1982)2, 89-102.

John Paul II, Uomo e donna lo creò, Città Nuova Editrice/Libreria Editrice Vaticana, Vatican City 1987.

Kant I., Grundlegung zur Metaphysik der Sitten, in: Kants Werke, Akademie-Textausgabe, Walter de Gruyter \& Co., Bd. IV, Berlin1968.

Laun A., Das Gewissen - sein Gesetz und seine Freiheit. Anmerkungen zur heutigen Diskussion, in: Aktuelle Probleme der Moraltheologie, ed. A. Laun, Herder \& Co., Wien 1991, 31-64.

Laun A., Das Gewissen. Oberste Norm sittlichen Handelns, Tyrolia, Innsbruck 1984.

Laun A., Die naturrechtliche Begründung der Ethik in der neueren katholischen Moraltheologie, Wiener Dom-Verlag, Wien 1973.

McCormick R., "Veritatis Splendor" and Moral Theology, America (1993) Oct 30, 8-11.

McCormick R., "Veritatis Splendor” in Focus: Killing the Patient, The Tablet (1993) Oct 30, 1410-1411.

McCormick R., Document begs many legitimate moral questions, National Catholic Reporter (1993) Oct 15, 17.

McCormick R., Some Early Reactions to "Veritatis Splendor", Theological Studies 55(1994), 481-506.

Menschen würde: Metaphysik und Ethik, ed. M. Crespo, Universitätsverlag C. Winter, Heidelberg 1998.

Qintás A.L., Qué es y qué motiva una acción moral?, presentación, tradd. de y ensayo introductorio de Mariano Crespo, Centro Universitario Francisco de Vitoria, Madrid 1995.

Schüller B., Direct Killing/Indirect Killing, in Readings in Moral Theology, No. 1. Moral Norms and Catholic Tradition, eds. Ch. E. Curran, R.A. McCormick, New York 1979, $141 \mathrm{ff}$.

Schüller B., Various Types of Grounding of Ethical Norms, in Readings in Mor al Theology, No. 1. Moral Norms and Catholic Tradition, 
eds. Ch. E. Curran, R.A. McCormick, Paulist Press, New York 1979, 184-198.

Seifert J., A volontade como perfeição pura e a nova concepção não-eudemonística do amor segundo Duns Scotus, traduzido do inglés por R. Hofmeister Pich, Veritas, Philosophische Fakultät, PUCRS, Porto Alegre, Brasilien 2005.

Seifert J., Das Leib-Seele Problem und die gegenwärtige philosophische Diskussion. Eine kritisch-systematische Analyse, Wissenschaftliche Buchgesellschaft, 2nd enlarged ed. Darmstadt 1989.

Seifert J., Dietrich von Hildebrand on Benevolence in Love and Friendship: A Masterful Contribution to Perennial Philosophy, Journal of Philosophical Inquiry and Discussion: Selected Papers on the Philosophy of Dietrich von Hildebrand, Quaestiones Disputatae 3(2013)2, 85-106.

Seifert J., Was ist und was motiviert eine sittliche Handlung?, Universitätsverlag A. Pustet, Salzburg 1976.

Smith J., "Veritatis Splendor", Proportionalism, and Contraception, http://mycatholicfaith.org/index.php?option=com_content\&view=article $\& \mathrm{id}=1734 \% 3$ Averitatis-splendor-proportionalism-and-contraception\&catid $=67 \% 3$ Ajanet-smith-articles \& Itemid $=133$

Styczeń T., John F. Crosbys Antwort auf das Referat von Tadeusz Styczeń sowie darauffolgende Diskussion, in: Menschenwürde: Metaphysik und Ethik. Jubiläumsband der Internationalen Akademie für Philosophie im Fürstentum Liechtenstein 1986-1996, ed. M. Crespo, Heidelberg 1998, 195-205.

Styczeń T., Zur Frage einer unabhängigen Ethik, in: Der Streit um den Menschen. Personaler Anspruch des Sittlichen, eds. K. Wojtyła, A. Szostek, T. Styczeń, Butzon und Bercker, Kevelaer 1979, 111-175. Wojtyła K., Love and Responsibility, trans. by H.T. Willetts, Ignatius Press, San Francisco 1993.

Wojtyła K., Szostek A., Styczeń T., Der Streit um den Menschen. Personaler Anspruch des Sittlichen, Butzon und Bercker, Kevelaer 1979. 